\title{
An Examination of the GaInP/GaInAs/Ge Triple Junction Solar Cell with the Analytical Solar Cell Model
}

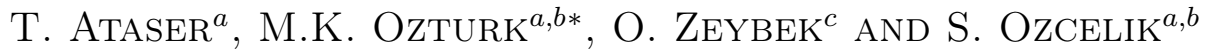 \\ ${ }^{a}$ Photonics Application and Research Center, Gazi University, 06500 Ankara, Turkey \\ ${ }^{b}$ Department of Physics, Faculty of Science, Gazi University, 06500 Ankara, Turkey \\ ${ }^{c}$ Department of Physics, Faculty of Arts and Sciences, Balikesir University, 10145, Balikesir, Turkey
}

(Received February 20, 2017; in final form January 2, 2019)

The photovoltaic energy is one of the most popular topics of research in the field of clean energy sources. It benefits directly from the sun, and has been accepted as a promising technology for the future. To this end, GaInP/GaInAs/Ge TJ solar cells, capable of being grown with the molecular beam epitaxy device, are designed along with tunnel junction layers. In this work, the analytical solar cell model is used for the calculation of solar cell performance. The calculation for the photo-response of the radiation spectrum of the solar cells includes an analytical solution equation in the model, including the continuity equations based on both the minority and majority carriers, the Poisson equation, and the current equation. For these calculations, Fortran programming language is used with high data sensitivity. The $J, V_{o c}$, and $\eta$ values of the GaInP/GaInAs/Ge TJ solar cell are calculated for the AM1.5G solar spectrum at temperatures in the range 200-450 K. The $\eta$ of the solar cell at room temperature under 1 sun is calculated as $35.114 \%$. As a result, triple or higher junction solar cell structures need to be designed in order to obtain greater efficiency.

DOI: 10.12693/APhysPolA.136.21

PACS/topics: multi-junction solar cell, modelling, GaInP/GaInAs/Ge, efficiency

\section{Introduction}

The need for energy of the human civilization being is increasing rapidly, influenced by the growing population and use of technology. Intensive studies are being conducted in order to meet the increasing energy requirements, and to obtain environment friendly and renewable energy sources as alternatives to the traditional ones. Among these studies, solar cells have revealed themselves to be an important option. Basically, the efficiency of solar cells operating as a semiconductor diode depends on the area of the cell, the angle of the radiation arriving on the cell, the humidity ratio in air, and the geographical location where the solar cell is installed [1,2]. We attempted to increase the efficiency obtained from multi-junction (MJ) solar cells by providing these conditions [3-5].

Nowadays, MJ solar cell made of III-V compound semiconductors is one of the most promising technologies for converting solar radiation into electrical energy. Current and lattice matching constructions are significant for MJ solar cells. Therefore, MJ solar cells have top to down low wavelength to high wavelength sequencing [6-8]. Thus, a high efficiency is achieved in the solar cells, owing to an optimized use of the solar spectrum, and consequently, with less thermalization loss. Every day, the sun provides us with $1.5 \times 10^{22} \mathrm{~J}$ charge-free energy, and, according to the literature, research is being conducted to increase the performance

*corresponding author; e-mail: ozturkm@gazi.edu.tr of the MJ solar cells used in terrestrial and space applications that will ensure to obtain the most benefit possible from this energy [9].

III-V MJ solar cells, such as GaInP/GaInAs / Ge triple junction (TJ) solar cells, have been commercially used at the highest efficiency. When we examine the outstanding solar cells in the literature, operating by the PV effect, we see that Bertness et al. determined in their study in 1994 that the efficiency of GaInP/GaAs/Ge TJ solar cells was $29.5 \%$ [10]. In 1995, Friedman et al. have obtained an efficiency for the GaInP/GaAs dual junction solar cell of $30.2 \%$ under 160 sun and the AM1.5D spectrum [11]. There have been many studies conducted in subsequent years with the purpose of increasing the efficiency of solar cells. As of 2006, an efficiency of over $40 \%$ was targeted for the GaInP/GaAs/Ge TJ solar cells. Masafumi et al. and Law et al. noted in 2008 that the efficiency of the TJ solar cells could be between $40 \%$ and $50 \%$ [12, 13]. The highest efficiency under concentration is calculated as $44.4 \%$ in the TJ solar cell studies that have been published until now [14]. In the study of Fetzer et al., the performance of triple junction GaInP/GaInAs/Ge solar cells was found to be $31.3 \%$ [15]. Today, there are intensive studies under 1 sun and under concentration, in order to improve the efficiency of TJ solar cells.

It is known that point, line, and volume defects in particular, deteriorate the structural (like lattice deformation), magnetic (like mobility), electrical (like solar cell performance), and optical (like energy band gap) features of the structure [16]. The situation that has come to the forefront, regarding structural defects in experimental studies, is that this constitutes a base for cracks in the structure by wave movement in the $c$-direction due 
to high dislocation density. This situation results in a situation where electron trappings or scattering mechanisms have a negative effect on the structure [16]. Taking these defects into consideration, the analytical solar cell model suggested by Schilinsky et al. is a suitable model for the $J-V$ characteristics of solar cells [17, 18]. This model provides absolute results for the calculation of the photoresponse of the radiation spectrum of solar cells and the performance of solar cells.

In this study, the electrical characteristic of the GaInP/GaInAs/Ge TJ solar cell structure are examined theoretically. Primarily, the energy band gap dependent absorption coefficient, which appears in the definition of the electrical property of the alloy at each lattice forming the layers, is calculated theoretically. Correspondingly, the temperature dependent (between 200 and $450 \mathrm{~K}$ ) cell out parameters $\left(J, V_{o c}\right.$, and $\eta$ ) of the GaInP/GaInAs/Ge TJ solar cell under AM1.5G spectrum and 1 sun are calculated by using the analytical solar cell model. In addition, the conversion efficiency of this TJ solar cell at room temperature under 454 sun is calculated. High solar cell performance is observed in this TJ solar cell at nanothickness, and in cubic structured layers with its low mobility and high carrier concentrations. The results are discussed within the parameters established in the literature.

\section{Solar cell structure}

The high efficiency $\mathrm{Ga}_{1-y} \operatorname{In}_{y} \mathrm{P} / \mathrm{Ga}_{1-x} \operatorname{In}_{x} \mathrm{As} / \mathrm{Ge}$ TJ solar cell structure is designed in order to be used in terrestrial applications. Therefore, the direct and scattered ray including $\mathrm{AM} 1.5 \mathrm{G}\left(1000 \mathrm{~W} / \mathrm{m}^{2}\right)$ are taken as reference [19]. The modelling of $\mathrm{Ga}_{1-y} \operatorname{In}_{y} \mathrm{P} / \mathrm{Ga}_{1-x} \operatorname{In}_{x} \mathrm{As} / \mathrm{Ge}$ TJ solar cell structure is shown schematically in Fig. 1. Three cells with $\mathrm{Ga}_{1-y} \operatorname{In}_{y} \mathrm{P}, \mathrm{Ga}_{1-x} \mathrm{In}_{x}$ As and Ge alloy are placed into the solar cell structure. These three cells are connected to each other serially with thin and ultra high doped tunnel junctions. These tunnel junctions provide low resistance and high current density. In the GaInP and AlGaAs structures, where a tunnel diode is used between the top cell and the middle cell, Si and Be may be added respectively in order to provide a high doped structure. Si and Be may be added respectively in order to establish a high doped $n$ - or $p$-type GaAs layer at the tunnel junction between the middle cell and the bottom cell at intervals $10^{16}$ and $10^{19}$. The parameters for the input parameters of the analytical solar cell method (which consists of quasi-experimental equations given in sections below) numerical solution, such as additive densities, thicknesses, mobility for the base and emitter layers, have been optimized. The thicknesses of the $\mathrm{Ga}_{1-y} \operatorname{In}_{y} \mathrm{P}, \mathrm{Ga}_{1-x} \operatorname{In}_{x} \mathrm{As}$, and Ge cells in the solar cells are optimized in order to ensure high efficiency. The doped concentrations of the base and emitter layers of the Ge bottom, $\mathrm{Ga}_{1-x} \operatorname{In}_{x}$ As middle, and $\mathrm{Ga}_{1-y} \operatorname{In}_{y} \mathrm{P}$ top cells are determined to be nearly $1 \times 10^{17}$, $1 \times 10^{18}$, and $1 \times 10^{16} \mathrm{~cm}^{-3}$, and nearly $1 \times 10^{19}, 1 \times 10^{19}$,

$\left.\begin{array}{|lr|}\hline \text { p- GaInP emitter } & 30 \mathrm{~nm} \\ \hline \mathbf{n}-\text { GaInP base } & 650 \mathrm{~nm}\end{array}\right]$ Top Cell

Fig. 1. The device architecture of the $\mathrm{Ga}_{1-y} \operatorname{In}_{y} \mathrm{P} /$ $\mathrm{Ga}_{1-x} \mathrm{In}_{x} \mathrm{As} / \mathrm{Ge}$ TJ solar cell.

and $1 \times 10^{18} \mathrm{~cm}^{-3}$, respectively. The mobilities of the $\mathrm{Ga}_{1-y} \operatorname{In}_{y} \mathrm{P}, \mathrm{Ga}_{1-x} \operatorname{In}_{x} \mathrm{As}$, and Ge cells are calculated as 4000, 7600, and $3900 \mathrm{~cm}^{2} /(\mathrm{V} \mathrm{s})$, respectively.

The GaInP, AlGaInP, AlGaAs, GaInAs, GaAs, and Ge structures used at the growth TJ solar cell have a stable isotropic structure in a cubic structure. Structure defects and the optical scattering mechanisms are unimportant values in these pure structures [20]. The calculations resulted in these values at values of one thousandth, and the results of the $J-V$ calculations did not change in this study.

The first step in the design of cells like $\mathrm{Ga}_{1-y} \operatorname{In}_{y} \mathrm{P} / \mathrm{Ga}_{1-x} \operatorname{In}_{x} \mathrm{As} / \mathrm{Ge}$ TJ solar cells is to determine the lattice constant matching and the appropriate energy band gap [20]. The indium (In) ratios of the $\mathrm{Ga}_{1-x} \operatorname{In}_{x} \mathrm{As}$ and $\mathrm{Ga}_{1-y} \operatorname{In}_{y} \mathrm{P}$ alloys are determined to be

$$
\begin{aligned}
& x=\frac{a_{\mathrm{Ga}_{1-x} \mathrm{In}_{x} \mathrm{As}}-a_{\mathrm{InAs}}}{a_{\mathrm{GaAs}}-a_{\mathrm{InAs}}}, \\
& y=\frac{a_{\mathrm{Ga}_{1-y} \mathrm{In}_{y} \mathrm{P}}-a_{\mathrm{InP}}}{a_{\mathrm{GaP}}-a_{\mathrm{InP}}},
\end{aligned}
$$

by using Vegard-based Eqs. (1) and (2), respectively. In this study the $x$ and $y$ values are the determined ratios. These determined values are not random but have values 0.17 and 0.65 in alloy, which increases the performance of the TJ solar cell beyond $40 \%$. These values are indicated in the literature experimentally [21]. The lattice constant length is fixed in compliance with these $x$ and $y$ values and high performance solar cells. Using Vegard's law the lattice constant lengths for GaInP and GaInAs are determined to be 5.723 and $5.724 \AA$ A, respectively, by utilizing $\mathrm{GaP}, \mathrm{InP}, \mathrm{GaAs}$, and InAs alloys. The lattice constant of these two layers seem to be matching, and these values are consistent with the values in the literature [22]. 


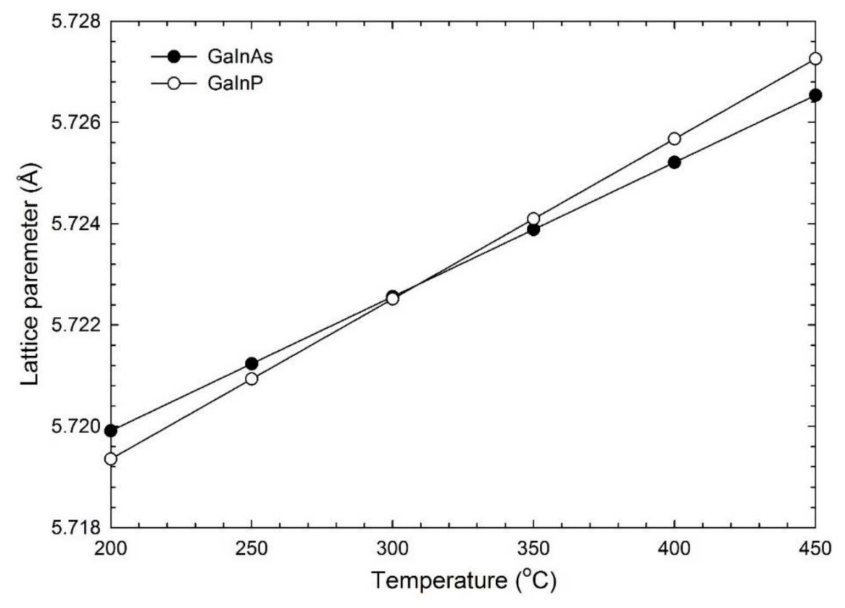

Fig. 2. The lattice constant lengths of the top and middle cell depending on the temperature.

The lattice constant length can be calculated as a function of temperature. The lattice constant lengths are calculated with the $\Delta a=\alpha \Delta t$ equation by utilizing the thermal expansion constant and the thermal strain values. Departing from Vegard's law, the GaInAs and GaInP thermal expansion constants are calculated as $5.525 \times 10^{-6}$ and $4.634 \times 10^{-6} /{ }^{\circ} \mathrm{C}$, respectively, by the thermal expansion constants of the $\mathrm{GaP}, \mathrm{InP}, \mathrm{GaAs}$, and InAs alloys. The lattice constant lengths of the top and middle cell for temperatures between 200 and $450 \mathrm{~K}$ are given in Fig. 2. As can be seen in Fig. 2, the crystal lattice lengths of the GaInAs vs. GaInP layers increase showing a linear behaviour along with the increase of temperature.

Due to the In content value $(x=0.17$ and $y=0.83)$ determined for TJ solar cells with Eqs. (1) and (2), the energy band gaps for GaInP and GaInAs are calculated based on Vegard's law as 1.67 and $1.18 \mathrm{eV}$, respectively. The Ge energy band gap is $0.65 \mathrm{eV}$.

Electromagnetic radiation, including solar radiation, consists of particles called photons, and the energy of a photon is calculated, by the equation

$$
E(e V)=\frac{1.24}{\lambda(\mu \mathrm{m})}
$$

and $\lambda$ is the photon's wavelength in $\mu \mathrm{m}$. Photons with a higher energy than the energy band gap are capable of generating energy when solar cells are exposed to light [23]. Therefore, the spectral composition of the solar radiation spectrum is important in the design of highly efficient solar cells.

The photogeneration of the electron-hole pair created in the semiconductor depends on the absorption coefficient of the semiconductor $(\alpha)$ and the photon flux $\left(\phi_{0}\right)$ [24]. The Ge [25], $\mathrm{Ga}_{1-x} \operatorname{In}_{x} \mathrm{As}$ [26] and $\mathrm{Ga}_{1-x} \operatorname{In}_{x} \mathrm{P}$ [27] absorption coefficients are calculated by the equation

$$
\begin{aligned}
& \alpha_{\mathrm{Ge}}(\lambda)=1.9 \sqrt{E-E_{g}} / E, \\
& \alpha_{\mathrm{Ga}_{1-x} \operatorname{In}_{x} \mathrm{As}}(\lambda)=3.3 \sqrt{E-E_{g}}
\end{aligned}
$$

$$
\begin{aligned}
& \alpha_{\mathrm{Ga}_{1-x} \operatorname{In}_{x} \mathrm{P}}(\lambda)= \\
& \quad 5.5 \sqrt{E-E_{g}}+1.5 \sqrt{E-E_{g}-0.1}
\end{aligned}
$$

where $E$ is the photon's energy, and $E_{g}$ is the energy band gap. When the unit is taken as $\mathrm{eV}$, unit of $\alpha$ will be determined to be $1 / \mu \mathrm{m}$.

\section{Results and discussion}

After the performance of the GaInP/GaInAs/Ge TJ designed solar cell, modeling by using the analytical solar cell model indicated that the temperature of the cell is changed between 200 and $450 \mathrm{~K}$, and changes to the cell out parameters were observed $[25,28]$. The change of the energy band gaps of the GaInP, GaInAs, and Ge semiconductor structures used in TJ solar cells depending on the temperature is calculated by the equation provided by Varshni [29]:

$$
E_{g}(T)=E_{g}(0)-\frac{\alpha T^{2}}{T+\beta},
$$

where $E_{g}(0)$ is the energy band gap of the semiconductor structure at $0 \mathrm{~K}, T$ is the temperature in $\mathrm{K}$, and the $\alpha$ and $\beta$ are the characteristic coefficients of the semiconductor. Figure 3 shows the change in the calculated energy band gaps for GaInP, GaInAs, and Ge semiconductor structures according to the temperature, and the energy band gap of the structures decreases with increase in the temperature. As shown in Fig. 3, the energy band gap of the structures decreases in the arrow direction according to the solar energy absorption sequence of the GaInP/GaInAs/Ge TJ solar cell structure. This means that the greater the energy band gap of a structure, the higher the absorbed photon quantity is. Therefore, in order to minimize current losses in MJ solar cell designs, the structure with the highest energy band gap is preferred in the top cell [30].

The short circuit current density $\left(J_{s c}\right)$ of the model TJ solar cell was calculated from the equations given in our previous work [31]. The $J-V$ characteristics of the solar cell is determined by Eq. (8):

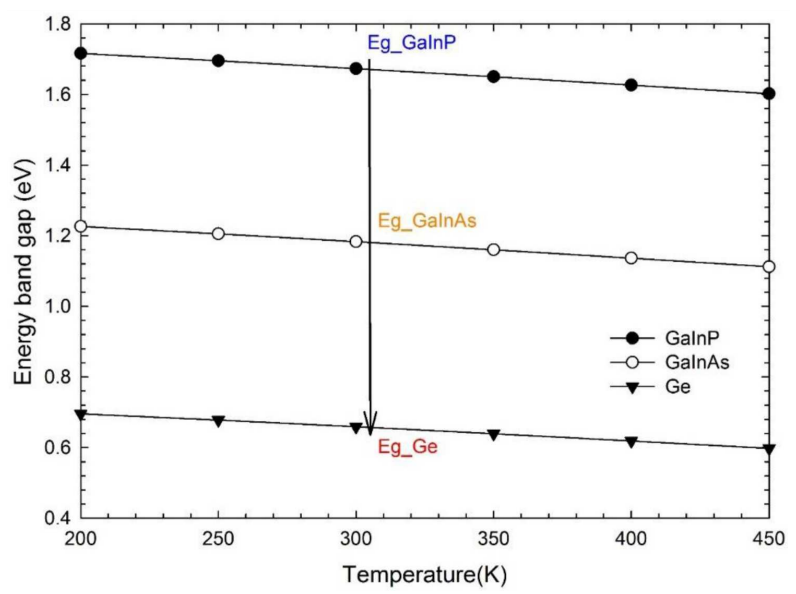

Fig. 3. Energy band gap of Ge, GaInAs and GaInP cells at different temperatures. 


$$
J=J_{s c}-J_{0}\left(\mathrm{e}^{\frac{q V_{o c}}{k T}}-1\right) .
$$

The open circuit voltage of the solar cell $\left(V_{o c}\right)$ is the maximum voltage, and the $V_{o c}$ is obtained by the equation when $J$ is taken to be zero in Eq. (8):

$$
V_{o c}=\frac{k T}{q} \ln \left(\frac{J_{s c}}{J_{0}}+1\right) .
$$

The $J-V$ characteristics of the GaInP/GaInAs/Ge TJ solar cell at temperatures varying between 200 and $450 \mathrm{~K}$ drawn under the AM1.5G solar spectrum is shown in Fig. 4. The high-resolution view is given as an inset graph within the graph since the current densities in the graph are close to each other. According to the theoretical calculations, the $J$ and $V_{o c}$ of the solar cell were calculated as $15.425 \mathrm{~mA} / \mathrm{cm}^{2}, 2.865 \mathrm{~V}$ at $200 \mathrm{~K}, 16.019 \mathrm{~mA} / \mathrm{cm}^{2}$, $2.348 \mathrm{~V}$ at $300 \mathrm{~K}$, and $16.575 \mathrm{~mA} / \mathrm{cm}^{2}, 1.558 \mathrm{~V}$ at $450 \mathrm{~K}$, respectively. As can be seen by these theoretical calculations, while the current density increases depending on the energy band gap decreasing by the temperature, the voltage decreases, with more increase in the temperature. As the solar cell generates more photocurrent due to the decrease in the energy band gap, the more the temperature of a semiconductor structure increases [32].

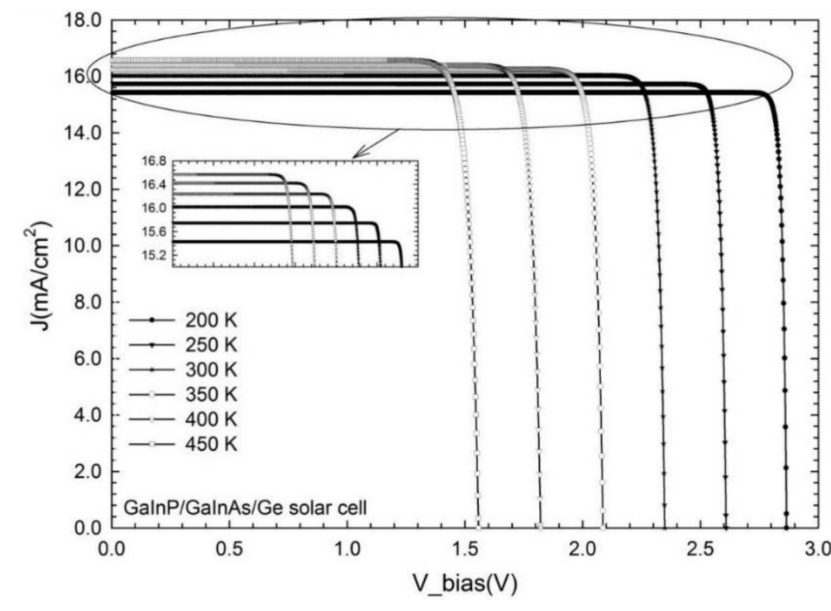

Fig. 4. Current density of the TJ solar cell at different temperatures.

The efficiency of the GaInP/GaInAs/Ge TJ solar cell is calculated by using Eq. (10):

$$
\eta=\frac{P_{\max }}{P_{\text {in }}}=F F \frac{V_{o c} I_{s c}}{P_{i n}} .
$$

The fill factor in the equation is determined theoretically with the equation provided by Green [24]:

$$
\mathrm{FF}=\frac{v_{o c}-\ln \left(v_{o c}+0,72\right)}{1+v_{o c}} .
$$

$v_{o c}$ is the normalized $V_{o c}$, and is determined by $v_{o c}=$ $V_{o c} / V_{T}$ and is $V_{T}=k T / q$. Left axis of Fig. 5 indicates the temperature dependent conversion efficiency of the GaInP/GaInAs/Ge TJ solar cell. The $V_{o c}$ decreases while the $J$ increases depending on the narrowing energy band gap when the temperature of a solar cell is

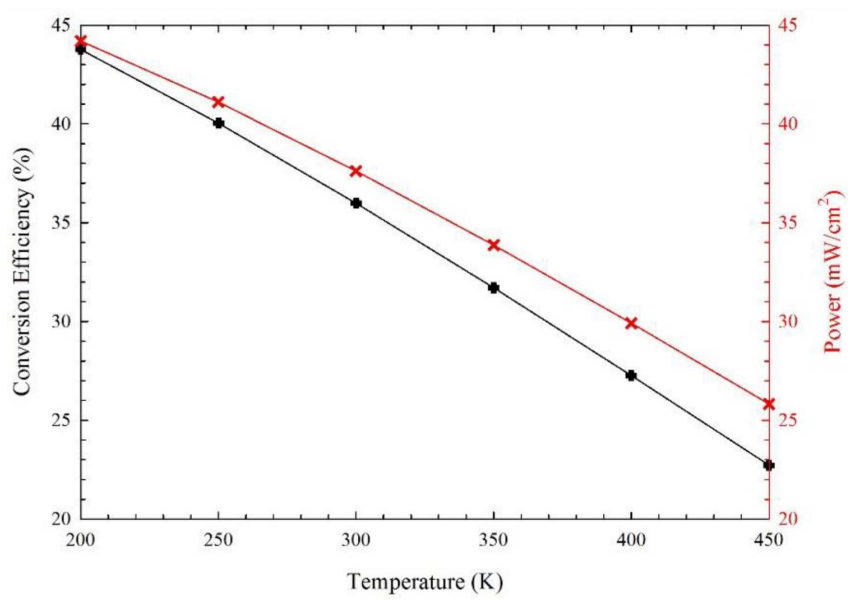

Fig. 5. Conversion efficiency and power of the TJ solar cell at different temperatures.

increased [33]. The decrease of the $V_{o c}$ is greater than the increase of the $J$, and thus the $\eta$ of the solar cell decreases with the increase of the temperature [34-36]. As can be seen in the figure, the $\eta$ of the GaInP/GaInAs/Ge TJ solar cell decreases along with the increase of temperature. While the calculated $\eta$ was $35.114 \%$ under 1 sun, this is calculated to be $42.69 \%$ under 454 sun at $300 \mathrm{~K}$. As can be seen in the results, $\eta$ of the cell increases proportionally to the increase of the solar concentration a solar cell, and the studies in the literature are consistent with this observation [37]. As can be seen in Fig. 5, it is observed that the $\eta$ increases at low temperatures. The reason for this can be that the phonon influences the optical characterization of the structure [19], because the electron-phonon interactions weaken at low temperatures, and the electron trappings are minimized. High efficiency at low temperatures provides an advantage in the radiation determination by the Ge detectors [38]. The $\eta$ of the GaInP/GaInAs/Ge TJ solar cell reaches the maximum limit value under optimal growing conditions. In order to exceed this value, it is possible to increase the performance of the cell by new TJ and MJ solar cells. Right axis of Fig. 5 shows the temperature dependent power of the GaInP/GaInAs/Ge TJ solar cell. As expected, the temperature-dependent efficiency and power curves give the same slope.

\section{Conclusion}

The parameters of the GaInP/GaInAs/Ge TJ solar cell were calculated numerically, making use of the analytical solar cell model. The calculations were performed by changing the temperature of the solar cell between 200 and $450 \mathrm{~K}$. Pursuant to the calculations as the lattice constant, the lattice constant length, energy band gap, absorption coefficient, current density, open circuit voltage, and conversion efficiency of the GaInP/GaInAs/Ge TJ solar cell were determined. The $J, V_{o c}$ and $\eta$ of the solar cell at room temperature were calculated as $16.019 \mathrm{~mA} / \mathrm{cm}^{2}, 2.348 \mathrm{~V}$, and $35.114 \%$, respectively. 
While the $J$ increases depending on the decreasing energy band gap, the $V_{o c}$ decreases, and, consequently, the $\eta$ of the solar cell decreases when the temperature of the cell is increased. The highest performance is seen at low temperatures. As a result of this study, the design of new solar cell structures can be carried out to increase performance. This situation requires the design of triple or multi-junction solar cells together with quaternary or more alloys in order to be able to adjust the wavelength to solar radiation better.

\section{Acknowledgments}

This work was supported by Development Ministry (TR), under the project no. 2016K121220.

\section{References}

[1] T.G. Amarnadh, G. Akshay, B.V. Shyam, Int. J. Renew. En. Res. 4, 628 (2014).

[2] S. Chakraborty, P.K. Sadhu, N. Pal Int. J. Renew. En. Res. 4, 1020 (2014).

[3] R.R. King, A. Boca, W. Hong, X.-Q. Liu, D. Bhusari, D. Larrabee, K.M. Edmondson, D.C. Law, C.M. Fetzer, S. Mesropian, N.H. Karam in: Proc. of the 24th European Photovoltaic Solar Energy Conference, Hamburg 2009, p. 55.

[4] H.-F. Hong, T.-S. Huang, W.-Y. Uen, Y.-Y. Chen, J. Nanomater. 2014, 1 (2014).

[5] S.K. Misra, C.P. Varma, A. Jaisal, IJAER 7, 1 (2012).

[6] M. Florescu, H. Lee, I. Puscasu, M. Pralle, L. Florescu, D.Z. Ting, J.P. Dowling, Sol. Energy Mater. Sol. Cells 91, 1599 (2007).

[7] J. Olson, D. Friedman, S. Kurtz, Handbook of PV Science and Engineering, Eds. A. Luque, S. Hegedus, New York 2002, p. 359.

[8] T. Markvart, L. Castañer, Solar Cells: Materials, Manufacture and Operation, Amsterdam 2005, p. 66.

[9] R.R. King, D.C. Law, K.M. Edmondson, C.M. Fetzer, G.S. Kinsey, H. Yoon, R.A. Sherif, N.H. Karam, Appl. Phys. Lett. 90, 183516 (2007).

[10] K.A. Bertness, S.A. Kurtz, D.J. Friedman, A.E. Kibbler, C. Kramer, J.M. Olson, Appl. Phys. Lett. 65, 989 (1994).

[11] D. Friedman, S.A. Kurtz, K.A. Bertness, A.E. Kibbler, C. Kramer, J.M. Olson, D.L. King, B.R. Hansen, J.K. Snyder, Prog. Photovolt. Res. Appl. 3, 47 (1995).

[12] Y. Masafumi, N. Ken-Ichi, S. Takuo, Solar Energy 82, 73 (2008).

[13] D.C. Law, R.R. King, H. Yoon, M.J. Archer, A. Boca, C.M. Fetzer, S. Mesropian, T. Isshiki, M. Haddad, K.M. Edmondson, D. Bhusari, J. Yen, R.A. Sherif, H.A. Atwater, N.H. Karam, Sol. Energy Mater. Sol. Cells 94, 1314 (2010).

[14] NREL, National Center for PVs, Best research-cell efficiencies chart, 2015.

[15] C.M. Fetzer, R.R. King, P.C. Colter, K.M. Edmondson, D.C. Law, A.P. Stavrides, H. Yoon, J.H. Ermer, M.J. Romero, N.H. Karam, J. Cryst. Growth 261, 341 (2004).
[16] B. Kınacı, Y. Ozen, K. Kızılkaya, T. Asar, S.S. Cetin, E. Boyalı, M.K. Öztürk, T. Memmedli, S. Özçelik, J. Mater. Sci. Mater. Electron. 24, 1375 (2013).

[17] P. Schilinsky, C. Waldauf, J. Hauch, C.J. Brabec, J. Appl. Phys. 95, 2816 (2004).

[18] S. Altazin, R. Clerc, R. Gwoziecki, G. Pananakakis, G. Ghibaudo, C. Serbutoviez, Appl. Phys. Lett. 99, 143301 (2011).

[19] S.J. Fonash, Solar Cell Device Physics, Academic Press, Amsterdam 1981, p. 4.

[20] D.J. Friedman Curr. Opin. Solid State Mater. Sci. 14, 131 (2010).

[21] W. Guter, J. Schöne, S.P. Philipps, M. Steiner, G. Siefer, A. Wekkeli, E. Welser, E. Oliva, A.W. Bett, F. Dimroth, Appl. Phys. Lett. 94, 223504 (2009).

[22] F. Dimroth, W. Guter, J. Schöne, E. Welser, M. Steiner, E. Oliva, A. Wekkeli, G. Siefer, S.P. Philipps, A.W. Bett, in: 2009 34th IEEE Photovoltaic Specialists Conference (PVSC), Philadelphia (PA) 2009, p. 001038.

[23] I. Vurgaftman, J.R. Meyer, L.R. Ram-Mohan, J. Appl. Phys. 89, 5815 (2001).

[24] S.M. Sze, K.K. Ng, Physics of Semiconductor Devices, Wiley, New York 1981, p. 730.

[25] L. Guijiang, W. Jyhchiarng, H. Meichun, J. Semicond. 31, 082004 (2010).

[26] J.M. Olson, S.R. Kurtz, A.E. Kibbler, P. Faine, Appl. Phys. Lett. 56, 623 (1990).

[27] A. Luque, S. Hegedus, Handbook of PV Science and Engineering, Wiley, England 2002, p. 74.

[28] L. Castafier, S. Silvestre, Modelling PV Systems using PSpice, Wiley, England 2002, p. 19.

[29] Y.P. Varshni, Physica 34, 149 (1967).

[30] R.R. King, D.C. Law, K.M. Edmondson, C.M. Fetzer, G.S. Kinsey, H. Yoon, D.D. Krut, J.H. Ermer, R.A. Sherif, N.H. Karam, Adv. OptoElectron. 2007, 29523 (2017).

[31] T. Ataser, N. Akın, O. Zeybek, S. Ozcelik J. OptoElectron. Adv. Mater. 18, 785 (2016).

[32] P. Singh, N.M. Ravindra, Sol. Energy Mater. Sol. Cells 101, 36 (2012).

[33] P. Singh, S.N. Singh, M. Lal, M. Husain, Sol. Energy Mater. Sol. Cells 92, 1611 (2008).

[34] K. Nishioka, T. Sueto, M. Uchida, Y. Ota, J. Electron. Mater. 39, 704 (2010).

[35] A.L. Fahrenbruch, R.H. Bube, Fundamentals of Solar Cells, Academic Press, New York 1983, p. 238.

[36] M.A. Steiner, J.F. Geisz, D.J. Friedman, W.J. Olavarria, A. Duda, T.E. Moriarty, in: 2011 37th IEEE Photovoltaic Specialists Conference, 2011, p. 002527.

[37] K. Nishioka, T. Takamoto, T. Agui, M. Kaneiwa, Y. Uraoka, T. Fuyuki, Sol. Energy Mater. Sol. Cells 90, 57 (2006).

[38] G. Duchene, F.A. Beck, P.J. Twin, G. de France, D. Curien, L. Han, C.W. Beausang, M.A. Bentley, P.J. Nolan, J. Simpson, Nucl. Instrum. Methods Phys. Res. A 432, 90 (1999). 